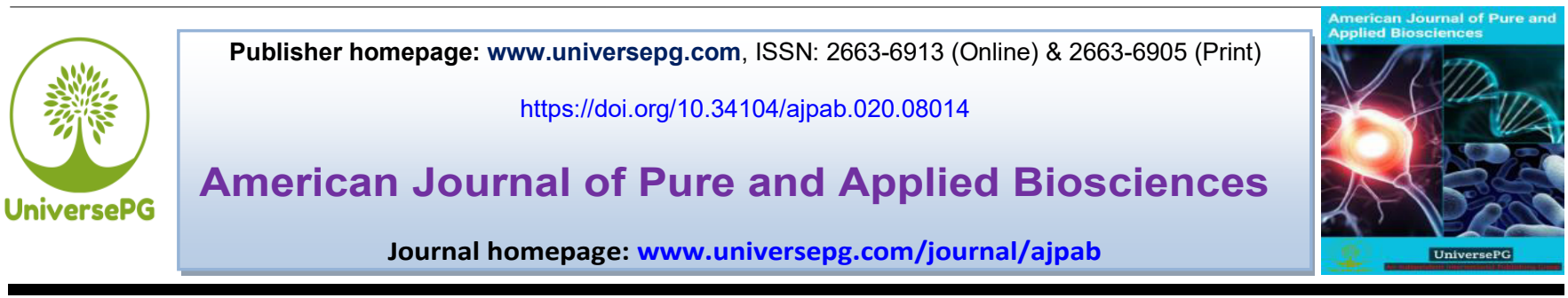

\title{
Determination of Optimum Survivability Factors of Highly Pathogenic Vibrio cholerae 01 Serogroup-Specific Bacteriophage JSF4 $\phi$
}

\author{
Mohammod Johirul Islam ${ }^{1}$, Titash Chandra Sarker ${ }^{1}$, Ruksana Akter Jebin ${ }^{1}$, Farjana Yasmin ${ }^{1}$, Mousumi \\ Khatun $^{1}$, Md. Ashraful Islam ${ }^{1}$, Sadia Binte Ramzan ${ }^{1}$, Fahim Alam Nobel ${ }^{1}$, Sharmin Akter ${ }^{1}$, Monira Islam ${ }^{1}$, \\ Mohammad Mehedi Hasan', Mst. Mahmuda Khatun', Shahnaz Yesmin ${ }^{1}$, Saima Sabrina ${ }^{1}$, Marina \\ Khatun', Abdullah Al Mamun', Md. Khairul Islam', Mohammad Asaduzzaman², Keshob Chandra Das ${ }^{3}$, \\ Mohammed Badrul Amin ${ }^{4}$, and Mohammad Khaja Mafij Uddin ${ }^{5}$
}

${ }^{1}$ Dept. of Biochemistry and Molecular Biology, Mawlana Bhashani Science and Technology University, Santosh, Tangail, Bangladesh; ${ }^{2}$ Dept. of Biochemistry, Primeasia University, Banani, Dhaka, Bangladesh; ${ }^{3}$ Dept. of Molecular Biotechnology, National Institute of Biotechnology, Savar, Bangladesh; ${ }^{4}$ Food Microbiology Laboratory, Laboratory Sciences and Services Division, ICDDR,B, Mohakhali, Dhaka, Bangladesh; and ${ }^{5}$ Mycobacteriology Laboratory, Infectious Disease Division, ICDDR,B, Mohakhali, Dhaka, Bangladesh

*Correspondence: johir75@yahoo.com

\begin{abstract}
Cholera is severe watery diarrhea caused by pathogenic $V$. cholerae 01 or 0139 serogroups. In each year, 2.9 millions of people are affected with cholera worldwide and 95000 deaths occur from the disease annually. In Bangladesh, around 100000 people are affected by this disease and approximately 4500 deaths occur each year. In this study, a novel $V$. cholerae 01 serogroup-specific bacteriophage JSF4 $\phi$ was used. This phage was able to lyse both the clinical and environmental pathogenic $V$. cholerae 01 serogroup strains and one of our previous studies demonstrated that the seasonal outbreaks of cholera caused by $V$. cholerae 01 serogroup strains in Bangladesh are mostly regulated by this bacteriophage. In this current study, we determined the optimum survivability factors of JSF4 $\phi$ bacteriophages. This study showed that the temperature $25^{\circ} \mathrm{C}$, $\mathrm{pH} 7$ and normal saline are the optimal survivability factors for JSF4 $\phi$ bacteriophages because, at these conditions, we have got the maximum number of plaque-forming unit $(\mathrm{PFU} / \mathrm{mL})$ of these bacteriophages. This study also showed that the JSF $4 \phi$ bacteriophages can survive at a wide range of temperature, $\mathrm{pH}$ and salinity. So, the study presented here may have an impact on the controlling of cholera epidemics caused by environmental and clinical pathogenic $V$. cholerae 01 serogroup strains if we can use JSF4 $\phi$ bacteriophages as a biocontrol agent. This study may also have profound implications for future studies of JSF4 $\phi$ bacteriophages as a good food additive or in phage therapy for its efficient lysing capacity against the pathogenic V. cholerae 01 serogroup strains.
\end{abstract}

Keywords: Cholera, Diarrhea, Vibrio cholerae, Optimum survivability, Pathogenic, and Bacteriophages.

\section{INTRODUCTION}

Vibrio cholerae is a facultative anaerobe, gramnegative, non-spore forming curved rod, about 1.04$1.06 \mu \mathrm{m}$ long. It is classified based on its somatic -

UniversePG I www.universepg.com antigens ( $\mathrm{O}$ antigens) into serovers or serogroups, and there are at least 155 known serogroups (Maheshwari et al., 2011). Serogroup 01 was supposed to include all the strains responsible for epidemic and endemic 
cholera. There are 154 known serogroups of non-01 vibrios. In 1992, a new serogroup, 0139 appeared in areas surrounding the Bay of Bengal produced major epidemics in India and Bangladesh, spread to neighboring countries, and continues to cause epidemic cholera in many of these areas (Shimada et al., 1995). V. cholerae 0139 was first identified in Bangladesh in 1992. This organism did not belong to any of the 138 known $\mathrm{O}$ serogroups of $V$. cholerae but to a new serogroup, which was later designated 0139. Hence, there are now two serogroups of $V$. cholerae, 01 and 0139 that have been associated with epidemic disease. Vibrios are the most common organisms in surface waters of the world (Jensen et al., 2006). They occur in both marine and freshwater habitats and associations with aquatic animals (Jensen et al., 2006, Zo et al., 2002, Sack et al., 2003). Cholera, whose "traditional home" has been the Ganges Delta and Southeast Asia, is one of man's oldest scourges. Cholera is characterized by severe watery diarrhea caused by pathogenic $V$. cholerae. A healthy person may become hypotensive within an hour of the onset of symptoms and may die within 2-3 hours if no treatment is provided (Todar et al., 2006; and Islam et al., 2020).

The meaning of bacteriophage is bacteria eater. Bacteriophages are approximately 50 times smaller than bacteria and ubiquitous in the soil, water, and several food products. They have also been isolated from humans and animals, for example from feces, urine, saliva, spit and serum (Jończyk et al., 2011). About $96 \%$ of them are tailed, but there are filamentous and pleomorphic ones as well (Jończyk et al., 2011, Ackermann et al., 2007, Hendrix et al., 2002). Generally, the phage virion consists of two basic components: nucleic acid (double- or singlestranded RNA or DNA) and a protein envelope (Jończyk et al., 2011; and Ackermann et al., 2003).

In this study, a novel $V$. cholerae 01 serogroupspecific bacteriophage JSF4 $\phi$, that infects both clinical and environmental pathogenic $V$. cholerae 01 strains were used. The outbreaks of cholera in Bangladesh are usually caused by pathogenic V. cholerae 01 or 0139 strains (Faruque et al., 2005). Since the JSF4 $\phi$ bacteriophages are very efficient to lyse both the clinical and environmental pathogenic $V$. cholerae 01 serogroup strains and one of our previous studies showed that the seasonal outbreaks of cholera caused by $V$. cholerae 01 serogroup in Bangladesh are mostly regulated by this bacteriophage (Faruque et al., 2005). So, it is important to know what the optimum survivability factors of these bacteriophages are. In this current study, we tried to determine the survivability factors of this bacteriophage and we have found that the temperature $25^{\circ} \mathrm{C}, \mathrm{pH} 7$ and normal saline are the optimal survivability factors for JSF4 $\phi$ bacteriophages because, at these conditions, we have got the maximum number of plaque-forming unit (PFU/mL) of these bacteriophages. This study also showed that the JSF $4 \phi$ bacteriophages can survive at a wide range of temperature, $\mathrm{pH}$ and salinity (Uddin et al., 2014).

So, the study presented here may have an impact on the controlling of cholera epidemics caused by the environmental and clinical pathogenic $V$. cholerae 01 strains if we can use JSF4 $\phi$ bacteriophages as a biocontrol agent in future. Since $V$. cholerae 01 serogroup strains are found in different types of food samples categorically including meat, fish, vegetables, fruits, street food, bakery shop food, fast food, sweets and dairy products (Mrityunjoy et al., 2013, . Lee et al., 2014), in future, we can also use JSF4 $\phi$ bacteriophages as a good food additive or in phage therapy with its efficient lysing capacity against pathogenic $V$. cholerae 01 strains.

\section{MATERIALS \& METHODS}

Media preparation: To prepare a nutrient broth, add $13 \mathrm{~g}$ of nutrient broth powder in $1 \mathrm{~L}$ of distilled water. Mix and dissolve them completely. Pour them into the conical flask. Sterilize by autoclaving at $121^{\circ} \mathrm{C}$ for 20 minutes. To prepare nutrient agar plat, dissolve the dehydrated medium in the appropriate volume of distilled water i.e., $28 \mathrm{gm}$ dehydrated nutrient agar in $1000 \mathrm{~mL}$ of distilled water. Sterilize by autoclaving at $121^{\circ} \mathrm{C}$ for 20 minutes and pour the sterilized media into $10 \mathrm{~cm}$ Petri dishes.

Growth of bacterial culture: Mainly two types of $V$. cholerae 01 serogroup strains were used in this experiment, one is clinical named N-16961 and 
another is environmental named Env-201. A single colony of $V$. cholerae 01 strain was inoculated into the nutrient broth and incubated at $37^{\circ} \mathrm{C}$ for overnight. To get a single colony of $V$. cholerae 01 strain, $V$. cholerae 01 cultured was streaked onto a nutrient agar plate and incubated at $37^{\circ} \mathrm{C}$ for overnight.

Collection and detection of $V$. cholerae 01 serogroup-specific bacteriophage JSF4 $\phi$ : We have collected $V$. cholerae 01 serogroup specific bacteriophage JSF4 $\phi$ from Molecular Genetics Laboratory, International Centre for Diarrhoeal Disease Research, Bangladesh (ICDDR,B). Faruque et.al isolated and purified this bacteriophage from environmental waters in Bangladesh (Faruque et al., 2005). After collection, we enriched the phage in $V$. cholerae 01 hosts strain named N-16961, then filtered with $0.22 \mu \mathrm{m}$ pore-sizes of filters (Millipore Corporation, Bedford, Mass.) to exclude bacteria and maintained the phage stock in normal saline at room temperature. We then detected and quantified JSF4 bacteriophages by the standard double layer plaque assay method as described previously (Faruque et al., 2005) and below.

Quantification of JSF4 bacteriophages: In order to enumerate $V$. cholerae 01 serogroup specific bacteriophages JSF4 by plaque assay method, logarithmicphase cells $(500 \mu \mathrm{L})$ of host $V$. cholerae 01 strain in nutrient broth were mixed with $3.5 \mathrm{ml}$ aliquots of soft agar (nutrient broth containing 0.8\% Agar), and the mixtures were over layed on nutrient agar plates. Dilutions of JSF4 $\phi$ bacteriophages were inoculated on the plates, and the plates were incubated for $16 \mathrm{~h}$ at $37^{\circ} \mathrm{C}$. A sample was considered positive for bacteriophages when a plaque was observed on the bacterial lawn. Plaques were counted to estimate the concentration of bacteriophage particles in the sample and expressed as PFU/mL.

Effect of temperature on the survivability of JSF4 bacteriophages: Temperature is a crucial factor for bacteriophage survivability. It plays a fundamental role in attachment, penetration, multiplication. At lower than optimal temperatures, fewer phages genetic material penetrates bacterial host cells; therefore, fewer of them can be involved in the multiplication phase. Higher temperatures can prolong the length of the latent stage. Moreover, temperature determines the occurrence, viability, and storage of bacteriophages. The impact of temperature on the JSF4 $\phi$ bacteriophages was examined at distinctive temperatures i.e. $15^{\circ} \mathrm{C}, 20^{\circ} \mathrm{C}, 25^{\circ} \mathrm{C}, 30^{\circ} \mathrm{C}, 40^{\circ} \mathrm{C}$, $50^{\circ} \mathrm{C}$.

To the determination of the optimum phage survivability at different temperatures, an equal number of JSF4 $\phi$ bacteriophages from the stock was added to normal saline, and the mixtures were incubated in preheated water at $15^{\circ} \mathrm{C}, 20^{\circ} \mathrm{C}, 25^{\circ} \mathrm{C}$, $30^{\circ} \mathrm{C}, 40^{\circ} \mathrm{C}$, and $50^{\circ} \mathrm{C}$ for 24 hours. After 24 hours incubation, the phage titers were estimated by the double-layer plaque assay method.

Effect of pH on the survivability of JSF4 $\phi$ bacteriophages: Development and survivability of microorganisms are fundamentally affected by nature's $\mathrm{pH}$. Bacteriophages can grow and develop at a particular $\mathrm{pH}$ range. This experiment was performed to determine the impact of $\mathrm{pH}$ on the survivability of JSF4 $\phi$ bacteriophages. To perform this experiment, an equal number of JSF4 $\phi$ bacteriophages from the stock were added to normal saline and the $\mathrm{pH}$ of saline was adjusted from 5 to 9 by using $\mathrm{HCl}$ or $\mathrm{NaOH}$ solution. The mixtures were then incubated for 24 hours at room temperature. After 24 hours incubation, the phage titers were quantified by the double-layer plaque assay method.

Effect of salinity on the survivability of JSF4 $\phi$ bacteriophages: Osmotic shock has been shown to inactivate bacteriophages (Jończyk et al., 2011) Bacteriophages can survive and show infectivity inside the cell at a particular saline concentration. The impact of salinity on JSF4 $\phi$ bacteriophages was examined at different saline concentrations i.e $1.2 \mathrm{~N}$, $0.9 \mathrm{~N}, 0.7 \mathrm{~N}, 0.3 \mathrm{~N}$.

To the determination of the optimum phage survivability at different saline concentrations, an equal number of JSF4 $\phi$ bacteriophages from the phage stock were added to the aforementioned saline concentrations and the mixtures were then incubated at room temperature for 24 hours. After 24 hours incubation, the phage titers were counted by the double-layer plaque assay method. 


\section{RESULTS \& OBSERVATION}

Effect of temperature on the lytic activity of JSF4 $\phi$ bacteriophages: Temperature is one of the most important environmental factors that strongly affect many aspects of the biological systems (Taj et al., 2014, Young et al., 2000, Wang et al., 2000). Temperature is a crucial factor for bacteriophage survivability (Jończyk et al., 2011, Olson et al., 2004, Srinivasan et al., 2007). Thermal survivability of $V$. cholerae 01 serogroup-specific bacteriophage JSF4 $\phi$ was determined after calculating the PFU in per millilitre of incubated samples through the appeared plaque count on the host bacterial strain (Fig 1A \& Fig 1B).
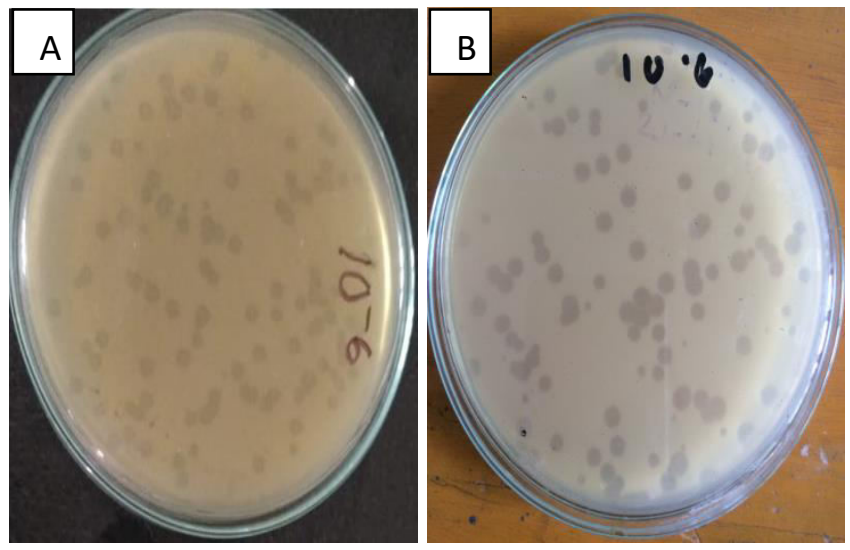

Fig 1: (A) Plaques of JSF4 $\phi$ bacteriophages on the lawn of host clinical $V$. cholerae 01 strain N-16961;

(B) Plaques of JSF4 $\phi$ bacteriophages on the lawn of host environmental $V$. cholerae 01 strain Env-201.

The impact of temperature on JSF4 $\phi$ bacteriophages was examined at distinctive temperatures i.e., $15^{\circ} \mathrm{C}$, $20^{\circ} \mathrm{C}, 25^{\circ} \mathrm{C}, 30^{\circ} \mathrm{C}, 40^{\circ} \mathrm{C}, 50^{\circ} \mathrm{C}$. It was found that the temperature $25^{\circ} \mathrm{C}$ is the optimal temperature for the survivability of JSF $4 \phi$ bacteriophages because at this temperature we have got the maximum number of phage particles $\left(1.62 \times 10^{11} \mathrm{PFU} / \mathrm{mL}\right)$ in the sample (Fig 2).

The lytic activity gradually declined when the bacteriophages were treated at less than or greater than $25^{\circ} \mathrm{C}$. No plaques were observed at $50^{\circ} \mathrm{C}$ (Fig 2). It might be due to the protein coat denaturation of bacteriophages. So, at this temperature, no phage particles were able to infect bacteria.

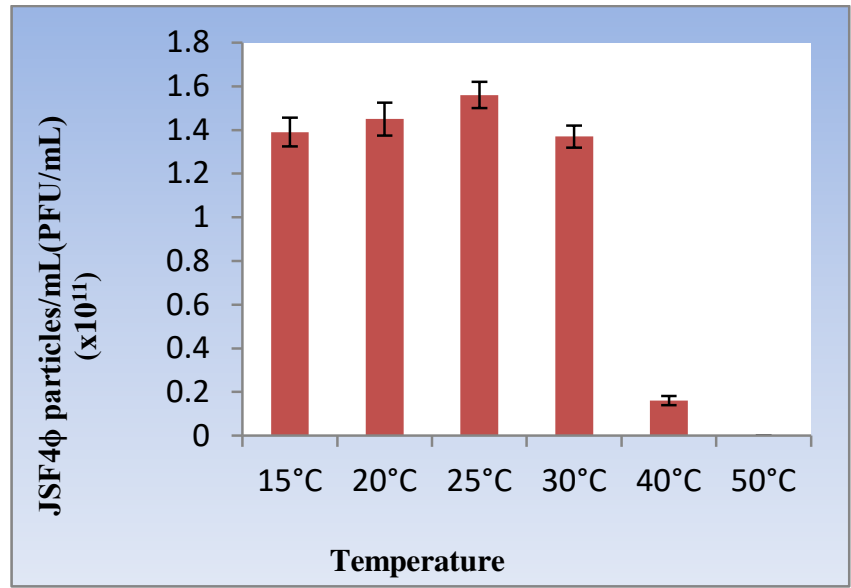

Fig 2: Effect of temperature on the lytic activity of JSF $4 \phi$ bacteriophages. Data shown are mean \pm S.D. of three individual experiments of each group of temperature.

Effect of pH on the lytic activity of JSF4 $\phi$ bacteriophages: $\mathrm{pH}$ is an important control factor for influencing attachment, infectivity, intracellular replication and multiplication of bacteriophages (Chatain-ly et al., 2014). Generally, studies on the lytic activity of bacteriophages have shown them to be most sensitive to $\mathrm{pH}$ values less than 5 and over 10 .

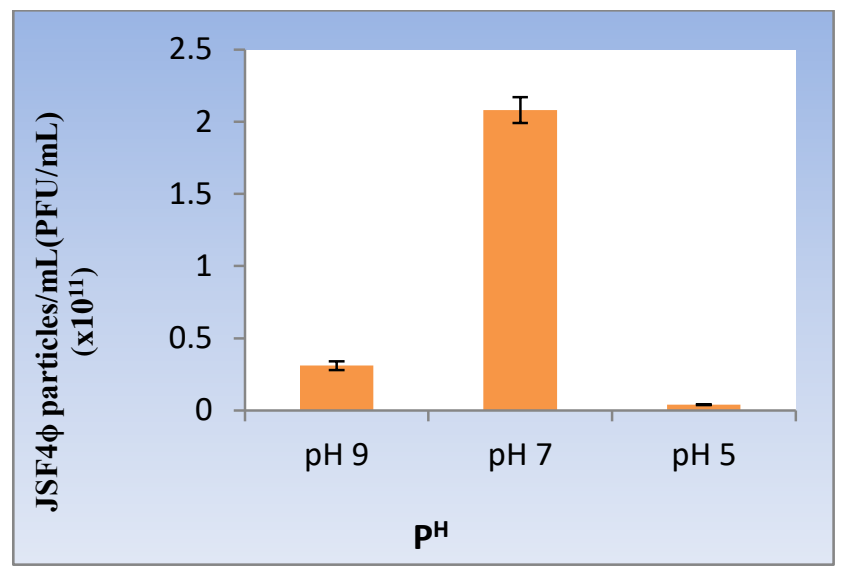

Fig 3: Effect of $\mathrm{pH}$ on the lytic activity of JSF4 $\phi$ bacteriophages. Data shown are mean \pm S.D. of three individual experiments of each group of $\mathrm{pH}$.

In the current study, we have found that the lytic activity of the JSF $4 \phi$ bacteriophages varied in the range of $\mathrm{pH} 5$ to 9 and the lysis activity showed highest at pH $7\left(2.08 \times 10^{11} \mathrm{PFU} / \mathrm{mL}\right)($ Fig 3). The lysis activity of JSF4 $\phi$ bacteriophages was gradually decreased when the bacteriophages were treated at less than or greater than of $\mathrm{pH} 7$ (Fig 3). This result 
indicates that $\mathrm{pH} 7$ is the optimal survival factor for JSF4 $\phi$ bacteriophages. At less than or greater than of $\mathrm{pH} 7$, the PFU of JSF4 $\phi$ bacteriophages decreased, it might be due to the alteration of the protein coat of bacteriophages, so the infectious capacity of phages becomes reduced.

Effect of salinity on the lytic activity of JSF4 $\phi$ bacteriophages: Osmotic shock has been shown to inactivate bacteriophages (Jończyk et al., 2011). The impact of salinity on JSF4 $\phi$ bacteriophages was examined at different saline concentrations i.e., $1.2 \mathrm{~N}$, $0.9 \mathrm{~N}, 0.7 \mathrm{~N}, 0.3 \mathrm{~N}$. From this experiment, we have found that the normal saline concentration $(0.9 \mathrm{~N} \mathrm{NaCl}$ solution) is the optimal survivability factor for JSF4 $\phi$ bacteriophages because at this concentration the bacteriophage JSF4 $\phi$ showed the highest lytic activity $\left(1.39 \times 10^{11} \mathrm{PFU} / \mathrm{mL}\right)$ (Fig 4). The lytic activity was gradually declined when the bacteriophages were treated at less than or greater than of $0.9 \mathrm{~N} \mathrm{NaCl}$ solution (Fig 4). This indicates that at less than or greater than of $0.9 \mathrm{~N} \mathrm{NaCl}$ solution, the PFU of JSF4 $\phi$ bacteriophages gradually reduced, it might be due to the osmotic shock of bacteriophages.

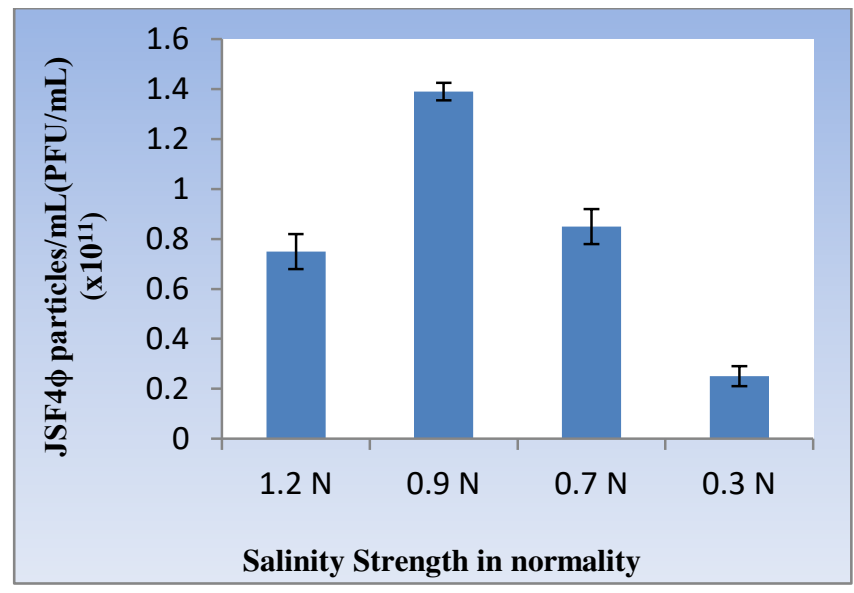

Fig 4: Effect of salinity on the lytic activity of JSF4 $\phi$ bacteriophages. Data shown are mean \pm S.D. of three individual experiments of each group of sodium chloride concentration.

\section{DISCUSSION}

Epidemics of cholera caused by pathogenic $V$. cholerae belonging to the 01 or 0139 serogroups are a major public health problem in many developing countries of Asia, Africa, and Latin America. In
Bangladesh, all the cholera pandemics except the seventh started because the people of this region come into direct contact with the surface water for drinking, bathing, cooking, and irrigation. Outbreaks of cholera caused deaths estimated at 95000 annually worldwide and many more cases each year, of which the vast majority occurs in children. It is threatening for people lived in the delta region for frequent emergence of multiple drug resistance $V$. cholerae 01 serogroup strains (Das et al., 2011; and Faruque et al., 2007).

The antibiotic resistance of $V$. cholerae 01 serogroup suggested that the development of alternative therapy is immediately needed. Lytic bacteriophages generally disrupt bacterial metabolism and lyse the bacterial host, indicating bactericidal activity. Besides, human phage therapy trials have shown a high level of safety without any side effects indicating safety for human applications (Bruttin et al., 2005, Sarker et al., 2016). Phages can be applied by oral, intraperitoneal, intravenous, or intranasal administration (Chatain-ly et al., 2014). V. cholerae isolated from 40 types of food samples categorically including meat, fish, vegetables, fruits, street food, bakery shop food, fast food, sweets, dairy products and seafood (Mrityunjoy et al., 2013). In 2006, the FDA approved the use and the preparation of bacteriophages generally recognized as safe (GRAS) as food additives for the control of the pathogenic bacterium $L$. monocytogenes in meat and poultry products (Chatain-ly et al., 2014).

Our current phage survivability study showed that the bacteriophage JSF4 $\phi$ can survive under a wide range of temperatures, $\mathrm{pH}$ and salinity. Moreover, these bacteriophages JSF4 $\phi$ are strongly able to lyse both the clinical and environmental pathogenic $V$. cholerae 01 serogroup strains suggesting that the bactericidal activity of these bacteriophages should be retained during food processing and preservation. So, we can use these bacteriophages as a good food additive in future. This bacteriophage can also be used as a good biocontrol agent in controlling the epidemics of cholera caused by pathogenic $V$. cholerae 01 serogroup strains. Furthermore, these bacteriophages JSF4 $\phi$ can be used in phage therapy with its efficient lysing capacity against $V$. cholerae 01 serogroup strains. 


\section{CONCLUSION}

In conclusion, our study demonstrated the survival parameters of $V$. cholerae 01 serogroup-specific bacteriophages JSF4 $\phi$ in laboratory condition. Even though this study did not simulate the survivability factors of the actual aquatic environment where these phages were habituated and first isolated from. As per as we know this study is the first of its kind for $V$. cholerae 01 serogroup-specific bacteriophages JSF4 $\phi$. We hope this study may have an impact on the controlling of cholera epidemics caused by environmental and clinical pathogenic $V$. cholerae 01 strains if we can use JSF4 $\phi$ bacteriophages as a biocontrol agent. This study will also have profound implications for future studies of JSF4 $\phi$ bacteriophages as a good food additive or in phage therapy for its efficient lysing activity.

\section{ACKNOWLEDGEMENTS}

We thank Dr. Shah Mohammad Faruque, a professor in the School of Life Sciences at Independent University Bangladesh for providing us bacteriophages and host strains. We also thank the Dept. of Biochemistry and Molecular Biology, Mawlana Bhashani Science and Technology University, Tangail, Bangladesh for its Lab facilities and logistic support.

\section{CONFLICT OF INTEREST}

All authors of this manuscript declare no conflict of interest to publish it.

\section{REFERENCES}

1. Ackermann, H.W., (2003). Bacteriophage observations and evolution. Research in Microbiology, 154(4), 245-251.

2. Ackermann, H.W., (2007). 5500 Phages examined in the electron microscope. Archives of virology, 152(2), 227-243.

3. Bruttin, A. and Brüssow, H., (2005). Human volunteers receiving $E$. coli phage T4 orally: a safety test of phage therapy. Antimicrobial agents and chemotherapy, 49(7), 2874-2878.

4. Chatain-ly, M.H., (2014). The factors affecting effectiveness of treatment in phages therapy. Frontiers in microbiology, 5, p.51.
5. Das, S., Choudhry, S., Saha, R., Ramachandran, V.G., Kaur, K. and Sarkar, B.L., (2011). Emergence of multiple drug resistance $V$. cholerae 01 in East Delhi. The $J$. of Infection in Developing Countries, 5(04), 294-298.

6. Faruque, S.M., Islam, M.J., Ahmad, Q.S., Faruque, A.S.G., Sack, D.A., Nair, G.B. and Mekalanos, J.J., (2005). Self-limiting nature of seasonal cholera epidemics: role of hostmediated amplification of phage. Proceedings of the National Academy of Sciences, 102(17), 6119-6124.

7. Faruque, S.M., Naser, I.B., Islam, M.J., Faruque, A.S.G., Ghosh, A.N., Nair, G.B., Sack, D.A. and Mekalanos, J.J., (2005). Seasonal epidemics of cholera inversely correlate with the prevalence of environmental cholera phages. Proceedings of the National Academy of Sciences, 102(5), 1702-1707.

8. Faruque, A.S., Alam, K., Malek, M.A., Khan, M.G., Ahmed, S., Saha, D., Khan, W.A., Nair, G.B., Salam, M.A., Luby, S.P. and Sack, D.A., (2007). Emergence of multidrugresistant strain of $V$. cholerae 01 in Bangladesh and reversal of their susceptibility to tetracycline after two years. J. of health, population, and nutrition, 25(2), p.241.

9. Hendrix, R., (2002). Bacteriophages: Evolution of the Majority. Theoretical Population Biology, 61(4), 471-480.

10. Islam, R., Hossain, Md.N., Alam, Md.K., Uddin, Md.E., Rony, M.H., Imran, Md.A.S., and Alam, Md.F. (2020). Antibacterial Activity of Lactic Acid Bacteria and Extraction of Bacteriocin Protein. Advances in Bioscience and Biotechnology, 11, 49-59.

https://doi.org/10.4236/abb.2020.112004

11. Jensen, M.A., Faruque, S.M., Mekalanos, J.J. and Levin, B.R., (2006). Modeling the role of bacteriophage in the control of cholera outbreaks. Proceedings of the National Academy of Sciences, 103(12), 4652-4657.

12. Jończyk, E., Kłak, M., Międzybrodzki, R. and Górski, A., (2011). The influence of external 
factors on bacteriophages. Folia microbiologica, 56(3), 191-200.

13. Lee, H.S., Choi, S., Shin, H., and Choi, S.H., (2014). Vibrio vulnificus bacteriophage SSP002 as a possible biocontrol agent. Appl. Environ. Microbiol. 80(2), 515-524.

14. Maheshwari, M., Nelapati, K. and Kiranmayi, B., (2011). Vibrio cholerae - A Review. Veterinary World, p.423.

15. Mrityunjoy, A., Kaniz, F., Fahmida, J., Shanzida, J.S., Aftab, U.M. and Rashed, N., (2013). Prevalence of $V$. cholerae in different food samples in the city of Dhaka, Bangladesh. International Food Research Journal, 20(2), p.1017.

16. Olson, M.R., Axler, R.P. and Hicks, R.E., (2004). Effects of freezing and storage temperature on MS2 viability. J. of virological methods, 122(2), 147-152.

17. Sack, R.B., Siddique, A.K., LonginiJr, I.M., Nizam, A., Yunus, M., Islam, M.S., Morris, Jr, J.G., Ali, A., Huq, A., Nair, G.B. and Qadri, F., (2003). A 4-year study of the epidemiology of $V$. cholerae in four rural areas of Bangladesh. The J. of infectious diseases, 187(1), 96-101.

18. Sarker, S.A., Sultana, S., Reuteler, G., Moine, D., Descombes, P., Charton, F., Bourdin, G., McCallin, S., Ngom-Bru, C., Neville, T. and Akter, M., (2016). Oral phage therapy of acute bacterial diarrhea with two coliphage preparations: a randomized trial in children from Bangladesh. EBioMedicine, 4, 124-137.

19. Shimada, T., Arakawa, E. and Takeda, Y., (1995). Epidemic of cholera due to a new serogroup V. cholerae O139 Bengal. Japanese J. of Bacteriology, 50(4), 1005-1017.
20. Srinivasan, P., Ramasamy, P., Brennan, G.P. and Hanna, R.E.B., (2007). Inhibitory effects of bacteriophages on the growth of Vibrio sp., pathogens of shrimp in the Indian aquaculture environment. Asian J. Anim. Vet. Adv, 2, 166183.

21. Taj, M.K., Ling, J.X., Bing, L.L., Qi, Z., Taj, I., Hassani, T.M., Samreen, Z. and Yunlin, W., (2014). Effect of dilution, temperature and $\mathrm{pH}$ on the lysis activity of T4 phage against $E$. coli bl21. J. Anim. Plant Sci, 24(4), 12521255.

22. Todar, K., (2006). Todar's online textbook of bacteriology. Madison, WI: Kenneth Todar, University of Wisconsin-Madison, Dept. of Bacteriology.

23. Uddin ME, Maitra P, Faruquee H. M., Alam MF. (2014). Isolation and Characterization of Proteases Enzyme from Locally Isolated Bacillus sp. American J. of Life Sciences, 2(6): 338-344. https://doi.org/10.11648/j.ajls.20140206.12

24. Wang, I.N., Smith, D.L. and Young, R., (2000). Holins: the protein clocks of bacteriophage infections. Annual Reviews in Microbiology, 54(1), 799-825.

25. Young, R.Y., Wang, N. and Roof, W.D., (2000). Phages will out: strategies of host cell lysis. Trends in microbiology, 8(3), 120-128.

26. Zo, Y.G., Rivera, I.N., Russek-Cohen, E., Islam, M.S., Siddique, A.K., Yunus, M., Sack, R.B., Huq, A. and Colwell, R.R., (2002). Genomic profiles of clinical and environmental isolates of $V$. cholerae $\mathrm{O} 1$ in cholera-endemic areas of Bangladesh. Proceedings of the National Academy of Sciences, 99(19), 12409-12414.

Citation: Islam MJ, Sarker TC, Jebin RA, Yasmin F, Khatun M, Islam MA, Ramzan SB, Nobel FA, Akter S, Islam M, Hasan MM, Khatun MM, Yesmin S, Sabrina S, Khatun M, Mamun AA, Islam MK, Asaduzzaman M, Das KC, Amin MB, and Uddin MKM. (2020). Determination of optimum survivability factors of highly pathogenic Vibrio cholerae 01 serogroup specific bacteriophage JSF4 $\phi$. American J. of Pure and Applied Biosciences, 2(2), 8-14. https://doi.org/10.34104/ajpab.020.08014 (C) 